\title{
Vegetation Cover Density and Land Surface Temperature Interrelationship Using Satellite Data, Case Study of Wadi Bisha, South KSA
}

\author{
Amalyahya Alshaikh \\ King Abdulaziz University, Jeddah, Saudi Arabia \\ Email: amal99sh@yahoo.com
}

Received 25 August 2015; accepted 27 September 2015; published 30 September 2015

Copyright (C) 2015 by author and Scientific Research Publishing Inc.

This work is licensed under the Creative Commons Attribution International License (CC BY).

http://creativecommons.org/licenses/by/4.0/

(c) (i) Open Access

\begin{abstract}
The aim of this study is to identify the relationship between Vegetation Cover (VC) and the land Surface Temperature (LST), using satellite data of Wadi Bisha, south the Kingdome of Saudi Arabia (KSA). The Landsat 7 Thematic Mapper (ETM) thermal band (band 6) was used for calculating the (LST) values. The near-infrared (NIR) and red band (bands 3 and 4 respectively) were used for estimating the vegetation cover. ERDAS Imagine 9.3 and ArcGIS 10.2 were used in the current study. The results of the study show that the increase of vegetation cover (VC) coincides with decrease of (LST), while the decrease in vegetation cover is linked with increase of (LST). It was found that there was no vegetation observed in areas practiced the highest temperature of $49^{\circ} \mathrm{C}$, while areas of lowest temperature of $28^{\circ} \mathrm{C}$ were characterized by dense vegetation cover. Thus, a quite significant correlation is approved between the (VC) and the (LST), based on the validation of (50) locations. It was concluded that availability and continuity of Satellite remote sensing data was required for elaborating a continuous monitoring of vegetation cover conditions and mapping was recommended in Wadi Bisha. Operational monitoring is recommended to ensure the adoption of flexible land cover validation protocols.
\end{abstract}

\section{Keywords}

Relationship, Vegetation Cover (VC), Land Surface Temperature (LST), Satellite Data, Wadi Bisha (South KSA)

\section{Introduction}

Advances in space technology have increasingly allowed the use of satellite data to study complex physical

How to cite this paper: Alshaikh, A. (2015) Vegetation Cover Density and Land Surface Temperature Interrelationship Using Satellite Data, Case Study of Wadi Bisha, South KSA. Advances in Remote Sensing, 4, 248-262. 
processes on the Earth's surface [1]. The importance of this study is to evaluate the use of remote sensed information, especially thermal bands to gain land surface temperature (LST), according to [2]. The LST values will be compared with vegetation cove density, extracted from the normalized difference vegetation index (NDVI). Land-surface temperature (LST) can be defined as the thermal emission from the landscape "surface", including the top of the canopy, for vegetated surfaces, as well as other surfaces (e.g. bare soils). Jinn and Dickinson [3] referred that LST controlled the surface heat and water exchange with atmosphere. Estimation of LST, from satellites infrared radiometers, has been proven useful. Most studies have focused on the use of polar orbiting satellite systems because of their high spatial resolution [4]. In estimation of LST from satellite thermal data, the digital number (DN) of image pixels needs to be converted into spectral radiance, using the sensor calibration data [5]. Landsat-7 Enhanced Thematic Mapper (ETM) scenes include a thermo band (band 6), which can detect thermal radiation released from objects on the earth surface, in addition to the red and near-infrared bands (band 3 and band 4). A vegetative index is a value derived from sets of remotely-sensed data that are used to quantify the vegetative cover on the Earth's surface. The NDVI is calculated as a ratio between measured reflectivity in the red and near infrared portions of the electromagnetic spectrum. These two spectral bands are chosen because they are most affected by the absorption of chlorophyll in leafy green vegetation and by the density of green vegetation on the surface. Also, in red and near-infrared bands, the contrast between vegetation and soil is at a maximum [6]. In this study, Landsat 7 ETM was used in order to estimate LST over Wadi Bisha (South KSA) and compared it with vegetation cover.

\section{Objectives}

The main objective of the current study is to investigate the generality of the LST-NDVI relationship over a wide range of moisture and climatic/radiation conditions, through the following steps:

1) Estimate NDVI Value from Satellite Images, using red and near-infrared bands (band 3 and band 4 of Landsat ETM 7).

2) Calculation of Land Surface Temperature (LST) from Satellite remote sensing data using the thermal band (band 6).

3) Finding out the relationship between normalized difference vegetation index (NDVI) and the land Surface Temperature (LST) in WadiBisha.

\section{Study Area}

The study area is located at the South of the Kingdom of Saudi Arabia (KSA) as shown in (Figure 1). The study area is characterized by diversity of its natural terrain, including plains, mountains and valleys where graded region height of (750 - $2850 \mathrm{~m}$ ) above sea level (Figure 2).

\section{Data}

The ETM data used in this study were obtained from a remote sensing satellite (Landsat 7) launched by National Aeronautics and Space Administration (NASA) of USA. A number of two images were used (Figure 3), images characteristics [7] are shown in Table 1.

\section{Methodology and Analyses}

In order to achieve the objectives of this study, the activities were elaborated in six main stages, while conducting subdividing the study area "WADI BISHA" into 4 parts to facilitate the application and analyses.

\subsection{Data Collection, Processing and Calibration of Raw Data and Geometric Correction}

The image processing software system (Erdas Imagine 9.3) was used for the geometric correction; calibration and processing of raw satellite data [8].

\subsection{Conversion of Thermo Band Digital Number (DN) to Spectral Radiance (L)}

For Landsat images that are not in the original United States Geological Survey (USGS) "GeoTIFF with Metatdata” format, it was needed to manually convert these data to radiance values. There are two formulas that can 


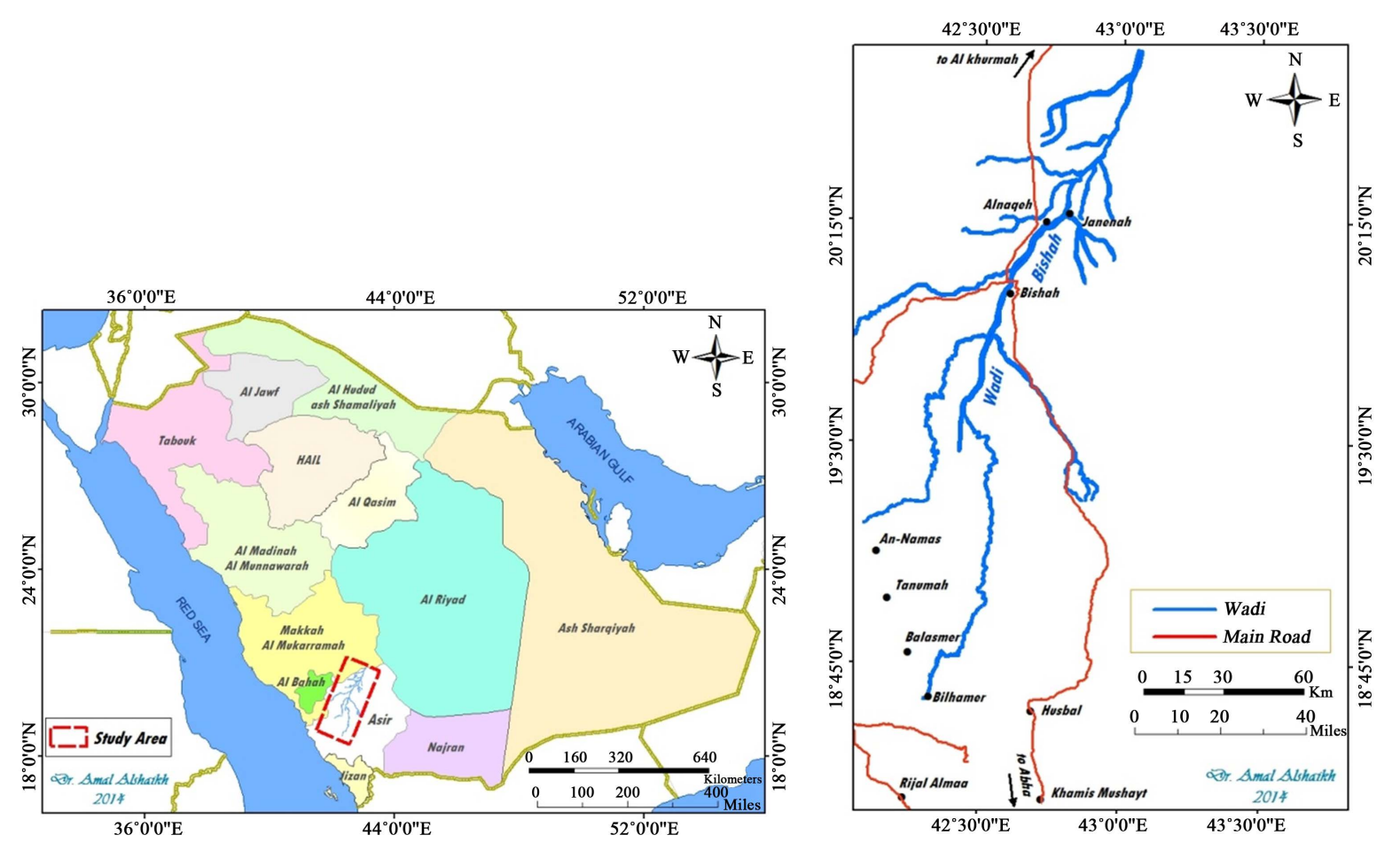

Figure 1. Location map of study area (between $\left(18^{\circ}-21^{\circ}\right) \mathrm{N}$ longitude and $\left(42^{\circ}-43^{\circ}\right)$ E latitude.

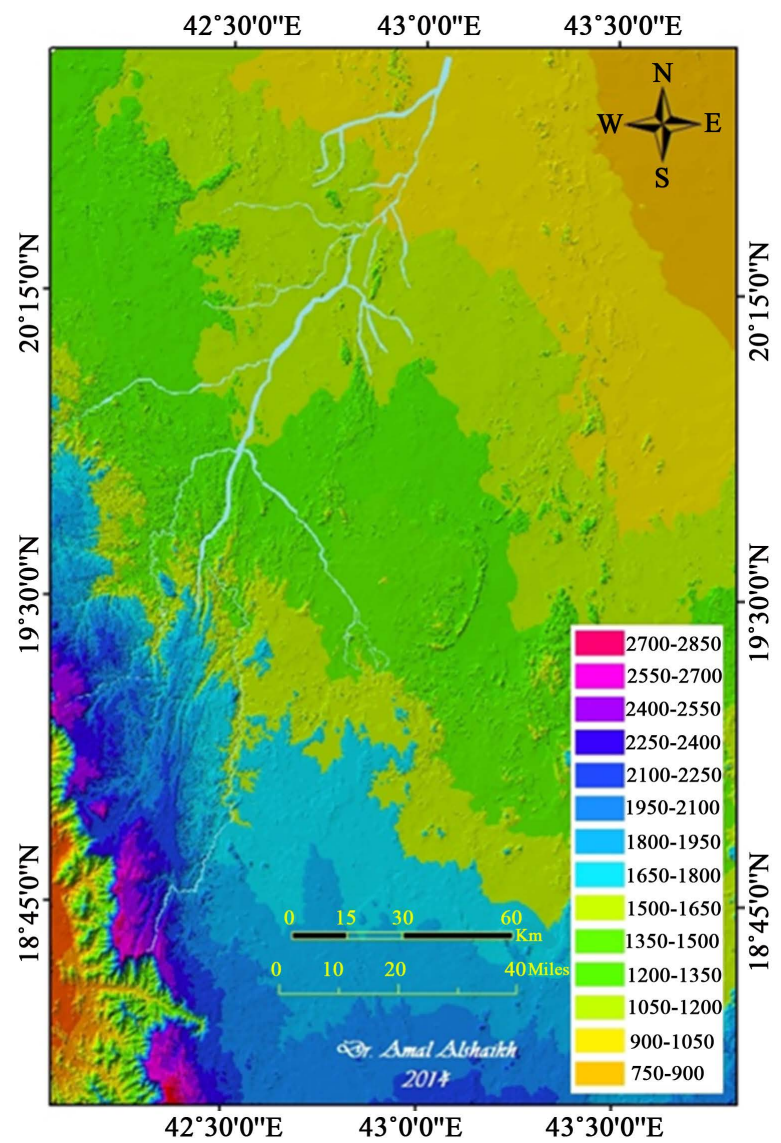

Figure 2. Topography of study area (altitude over sea level). 


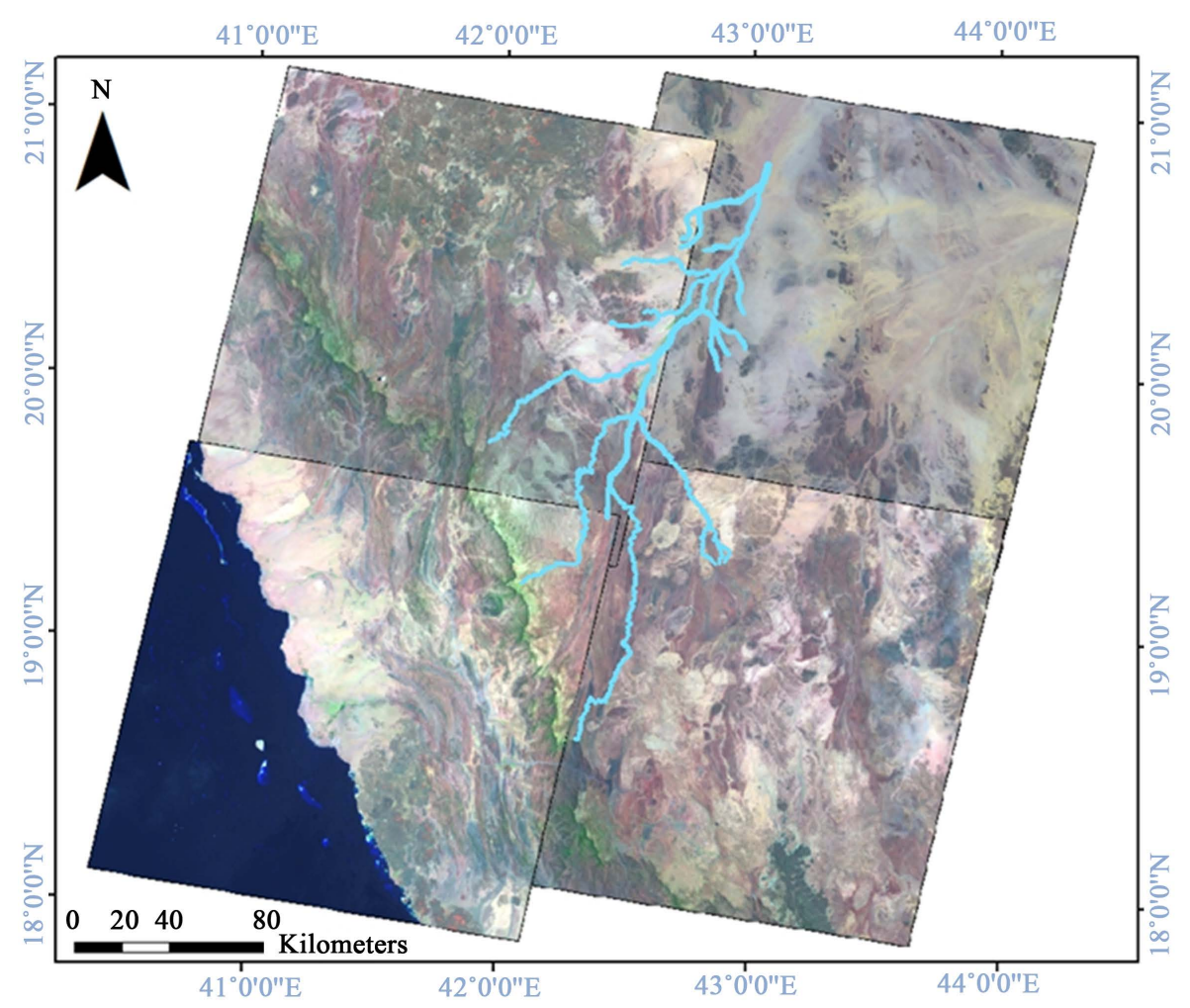

Figure 3. Satellite images covering study area.

Table 1. Spectral characteristics of Landsat 7 ETM images.

\begin{tabular}{ccc}
\hline Band & Wave length (Micrometers) & Spatial resolution (Meters) \\
\hline Band 1 & $0.45-0.52$ & 30 \\
Band 2 & $0.52-0.60$ & 30 \\
Band 3 & $0.63-0.69$ & 30 \\
Band 4 & $0.77-0.90$ & 30 \\
Band 5 & $1.55-1.75$ & 30 \\
Band 6 & $10.40-12.50$ & 60 \\
Band 7 & $2.9-2.35$ & 30 \\
\hline
\end{tabular}

METADATA; SPACECRAFT_ID = "Landsat7"; SENSOR_ID = "ETM+"; ACQUISITION_DATE = 2000-08-24 and 2000-06-21; WRS_PATH = 167; WRS_ROW = 046 and 047; REFERENCE_DATUM = "WGS8"; REFERENCE_ELLIPSOID = "WGS84"; MAP_PROJECTION = "UTM (Universal Transverse Mercator)"; ZONE_NUMBER = +38.

be used to convert DN's to radiance; the method depends on the scene calibration data available in the header file ([9] and [10]. One method uses the Gain and Bias (or Offset) values from the header file. The longer method uses the LMin and LMax spectral radiance scaling factors. The following formulas have been adapted from the USGS Landsat Users handbook [11].

\section{A. Gain and Bias Method:}

The formula to convert DN to radiance using gain and bias values is:

$$
\mathrm{CV}_{\mathrm{R}}=\mathrm{G}\left(\mathrm{CV}_{\mathrm{DN}}\right)+\mathrm{B}
$$

where:

$\mathrm{CV}_{\mathrm{R}}$ is the cell value as radiance, 
$\mathrm{CV}_{\mathrm{DN}}$ is the cell value digital number,

$G$ is the gain value for a specific band,

$B$ is the bias value for a specific band,

B. $\mathrm{L}_{\text {Min }}$ and $\mathrm{L}_{\mathrm{Max}}$ Method:

The formula to convert $\mathrm{DN}$ to radiance using $\mathrm{L}_{\min }$ and $\mathrm{L}_{\max }$ values is:

$$
\mathrm{L}=\mathrm{LMIN}+(\mathrm{LMAX}-\mathrm{LMIN}) * \mathrm{DN} / 255
$$

where:

$\mathrm{L}=$ Spectral radiance,

LMIN = (Spectral radiance of DN value 1$)$,

LMAX $=($ Spectral radiance of DN value 255$)$,

DN = Digital Number.

Table 2 lists these values for ETM band 6 for the two images

Using these values in Table 2 absolute radiance values can calculate for each pixel in the two images. It should be noticed that the radiance values are real numbers, while the DN values in Band 6 are integers.

\subsection{Conversion of Spectral Radiance to Temperature in Kelvin}

Once the DN's values for the thermal bands have been converted to radiance values, it is simply a matter of applying the inverse of the Planck function to derive temperature values.

The formula to convert radiance to temperature is:

$$
\mathrm{T}=\mathrm{K}_{2} / \operatorname{Ln}\left\{\left(\mathrm{K}_{1} * \varepsilon\right) / \mathrm{CV}_{\mathrm{R} 1}+1\right\}
$$

where:

$\mathrm{T}=$ Effective at-satellite temperature in Kelvin,

$\mathrm{K}_{2}=$ Calibration constant 2 from Table 3,

$\mathrm{K}_{1}=$ Calibration constant 1 from Table 3,

$\mathrm{CV}_{\mathrm{R} 1}=$ is the cell value as radiance,

$\varepsilon=$ is emissivity (typically 0.95 ).

\subsection{Conversion of Temperatures}

The temperature values are estimated in degrees Kelvin, and are then converted to degree Celsius.

\subsection{Calculation (NDVI) Values}

A vegetative index is a value that is derived from sets of remotely-sensed data that is used to quantify the vegetative cover on the Earth's surface. The NDVI is calculated as a ratio between measured reflectivity in the red and near infrared portions of the electromagnetic spectrum. These two spectral bands are chosen because they are most affected by the absorption of chlorophyll in leafy green vegetation and by the density of green vegetation on the surface. Also, in red and near-infrared bands, the contrast between vegetation and soil is at a maximum.

The Thematic Mapper bands 3 and 4 provide red and near-infrared measurements respectively and therefore can be used to generate NDVI data sets with the following formula.

Table 2. Values of LMIN and LMAX for the Landsat 7 ETM.

\begin{tabular}{ccc}
\hline Parameters & LMIN & LMAX \\
\hline Landsat-7 ETM P/R-167/46 (2000-08-24) & 3.200 & 12.65 \\
Landsat-7 ETM P/R-167/47 (2000-06-21) & 3.200 & 12.65 \\
\hline
\end{tabular}

Table 3. Landsat 7 ETM thermal band calibration constants.

\begin{tabular}{ccc}
\hline Satellite & Constant 1-K1 watts/(meter squared/ster/ $\mathbf{\mu m})$ & Constant 2-K2 Kelvin \\
\hline Landsat 7 & 666.09 & 1282.71 \\
\hline
\end{tabular}




$$
\begin{gathered}
\mathrm{NDVI}=(\mathrm{NIR}-\mathrm{RED}) /(\mathrm{NIR}+\mathrm{RED}) \\
\mathrm{NDVI}=(\text { Band} 4-\text { Band} 3) /(\text { Band} 4+\text { Band} 3)
\end{gathered}
$$

\subsection{Relationship between Vegetation Cover and (LST)}

Software (ArcGIS-ArcInfo 10.0) were used to prepare maps that represent the relationship between vegetation cover and (LST) in addition to the preparation of all study result maps.

\section{Results}

\subsection{VC and LST Pattern and Interrelationship in Wadi Pisha}

The relationship, between Vegetation Cover (VC) and (LST) of the Four Parts of Wadi Bisha, are presented in the following Figures, Tables, and graphs. Regarding the first part, Figure 4 \& Figure 5 and Table 4 demonstrate the distribution of LST and VC respectively. Table 4 demonstrates the relationship between the two parameters. It is found that LST values range between $30^{\circ} \mathrm{C}$ to $48^{\circ} \mathrm{C}$ while NDVI values between 0.19 and 0.34 . Figure 6 shows a negative correlation coefficient of -0.96 between the two parameters.

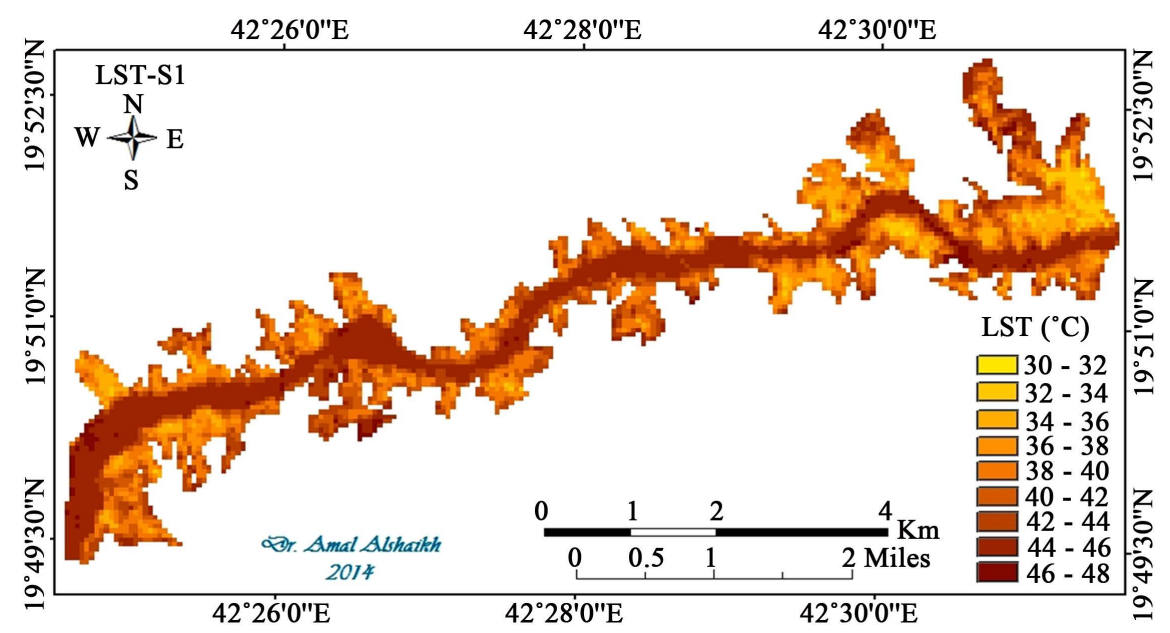

Figure 4. LST (Celsius) in the first part.

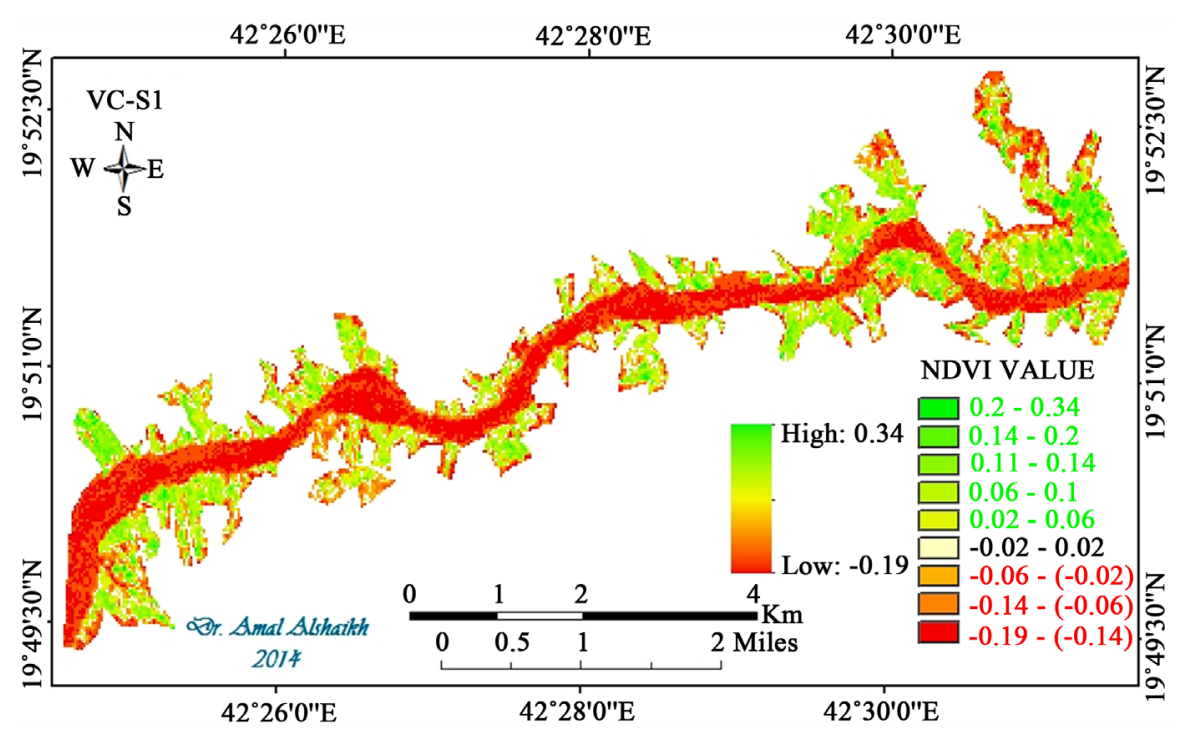

Figure 5. NDVI value in the first part. 


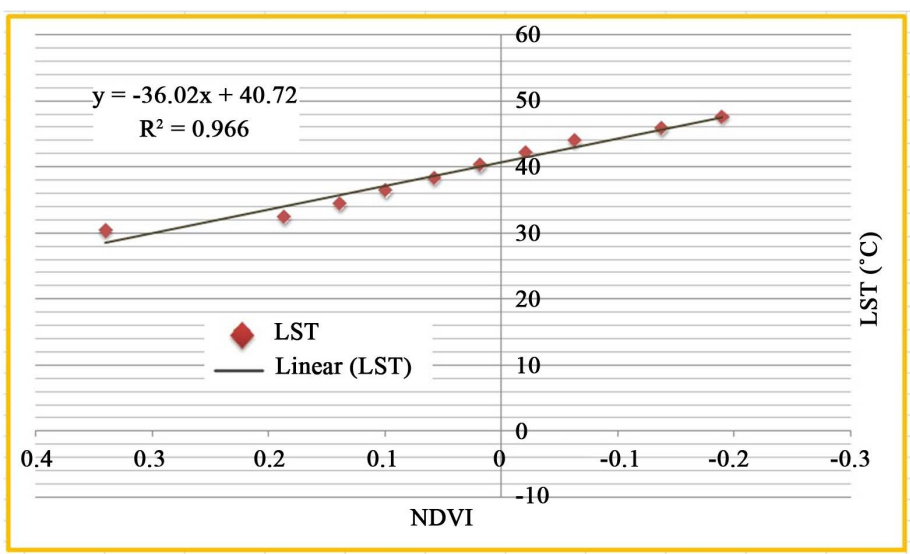

Figure 6. Relationship between LST and NDVI at part 1.

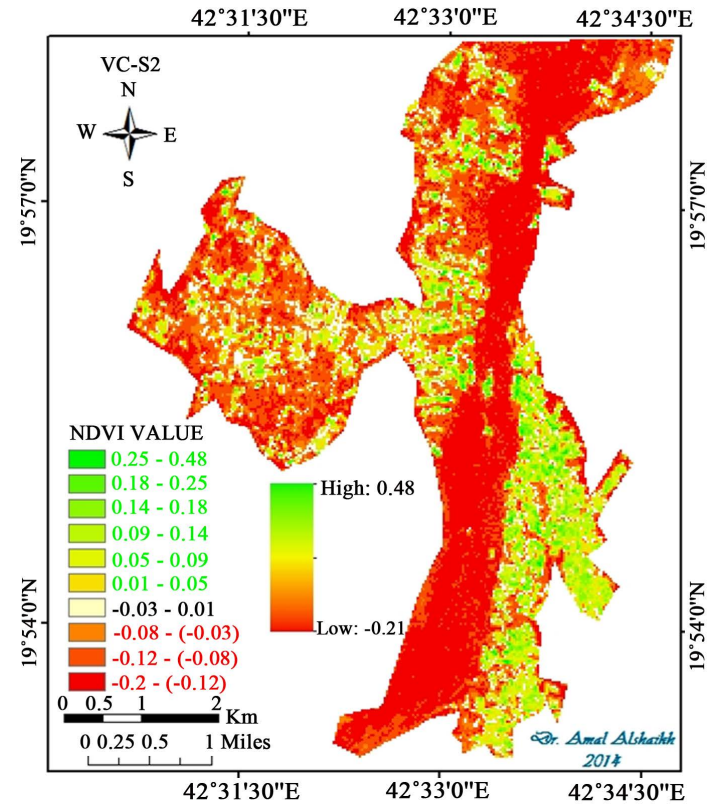

Figure 7. LST (Celsius) in the second part.

Table 4. LST and NDVI measurement at part 1.

\begin{tabular}{ccccc}
\hline Pixel Value & Radiance & LST (Kelvin) & LST (Degree) & NDVI_VALUE \\
\hline 166 & 9.338779528 & 303.1976768 & 30.1976768 & 0.3405 \\
174 & 9.636417323 & 305.4292583 & 32.4292583 & 0.1868 \\
181 & 9.896850394 & 307.3512105 & 34.3512105 & 0.139 \\
188 & 10.15728346 & 309.2458629 & 36.2458629 & 0.09957 \\
195 & 10.41771654 & 311.1143996 & 38.1143996 & 0.05802 \\
203 & 10.71535433 & 313.2193053 & 40.2193053 & 0.01855 \\
210 & 10.9757874 & 315.0355067 & 42.0355067 & -0.02092 \\
217 & 11.23622047 & 316.828828 & 43.828828 & -0.06247 \\
224 & 11.49665354 & 318.6001664 & 45.6001664 & -0.1372 \\
232 & 11.79429134 & 320.5987138 & 47.5987138 & -0.1892 \\
\hline
\end{tabular}


The first part is characterized as follow: LST (Kelvin) $=(303.1976768-320.5987138)$. LST (Celsius) $=$ $\left(30^{\circ} \mathrm{C}-48^{\circ} \mathrm{C}\right)$. NDVI Value $(0.19-0.34) . \mathrm{R}=-0.98322 . \mathrm{R}^{2}=0.966$ (Figure 6).

In regard with part 2 of Wadi Bisha, the distribution of LST and NDVI values are shown in Figure 7 and Figure 8 respectively. Table 5 demonstrates the values of the two parameters in different locations. It is found that LST ranges between $30^{\circ} \mathrm{C}$ to $49^{\circ} \mathrm{C}$, while NDVI between 0.20 and 0.48 . Table 5 and Figure 9 show that a negative correlation coefficient of 0.98 cauterizes the relation between the two parameters.

The second part is characterized as follow: (Figure 7 and Figure 8) (Table 5). LST (Kelvin) $=(302.633713$ 322.3257189). LST (Celsius) $=\left(30^{\circ} \mathrm{C}-49^{\circ} \mathrm{C}\right)$. NDVI Value $(0.2-0.48) . \mathrm{R}=-0.96896 . \mathrm{R}^{2}=0.938$ (Figure 9).

Distribution of LST and NDVI, at the third part 3 of Wadi Bisha, is shown in Figure 10 and Figure 11 respectively. Table 6 demonstrates the values of the two parameters in different locations. It is found that LST ranges between $31^{\circ} \mathrm{C}$ to $46^{\circ} \mathrm{C}$, while NDVI ranged between 0.21 and 0.29 . A negative correlation coefficient of 0.98 characterizes the relation between the two parameters.

The third part is characterized as follow: LST (Kelvin) $=(304.3182571-319.3527926)$. LST (Celsius) $=$ $\left(31^{\circ} \mathrm{C}-46^{\circ} \mathrm{C}\right)$. NDVI Value $(0.21-0.29) . \mathrm{R}=-0.97987 . \mathrm{R}^{2}=0.960$ (Figure 12).

Regarding the Forth part of Wadi Bisha, the distribution of LST and NDVI is shown in Figure 13 and Figure 14 respectively. It is found that LST ranges between $28^{\circ} \mathrm{C}$ to $47^{\circ} \mathrm{C}$, while NDVI lies between -0.30 and 0.42. A negative correlation coefficient 0.98 (Table 7 and Figure 15) is found between the two parameters.

The forth part is characterized as follow: (Figure 13 and Figure 14) (Table 7). LST (Kelvin) $=(300.6399705$ - 319.8524179). LST (Celsius) $=\left(28^{\circ} \mathrm{C}-47^{\circ} \mathrm{C}\right)$. NDVI value $(0.303-0.42) . \mathrm{R}=-0.99245 . \mathrm{R}^{2}=0.985$ (Figure 15).

\subsection{Validation of VC-LST Relationship}

Finally, a number of 10 geographic locations were chosen randomly to represent the study area, for measuring both LST and NDVI. The measurements show that LST ranges between $33^{\circ} \mathrm{C}$ to $49^{\circ} \mathrm{C}$, while NDVI values range

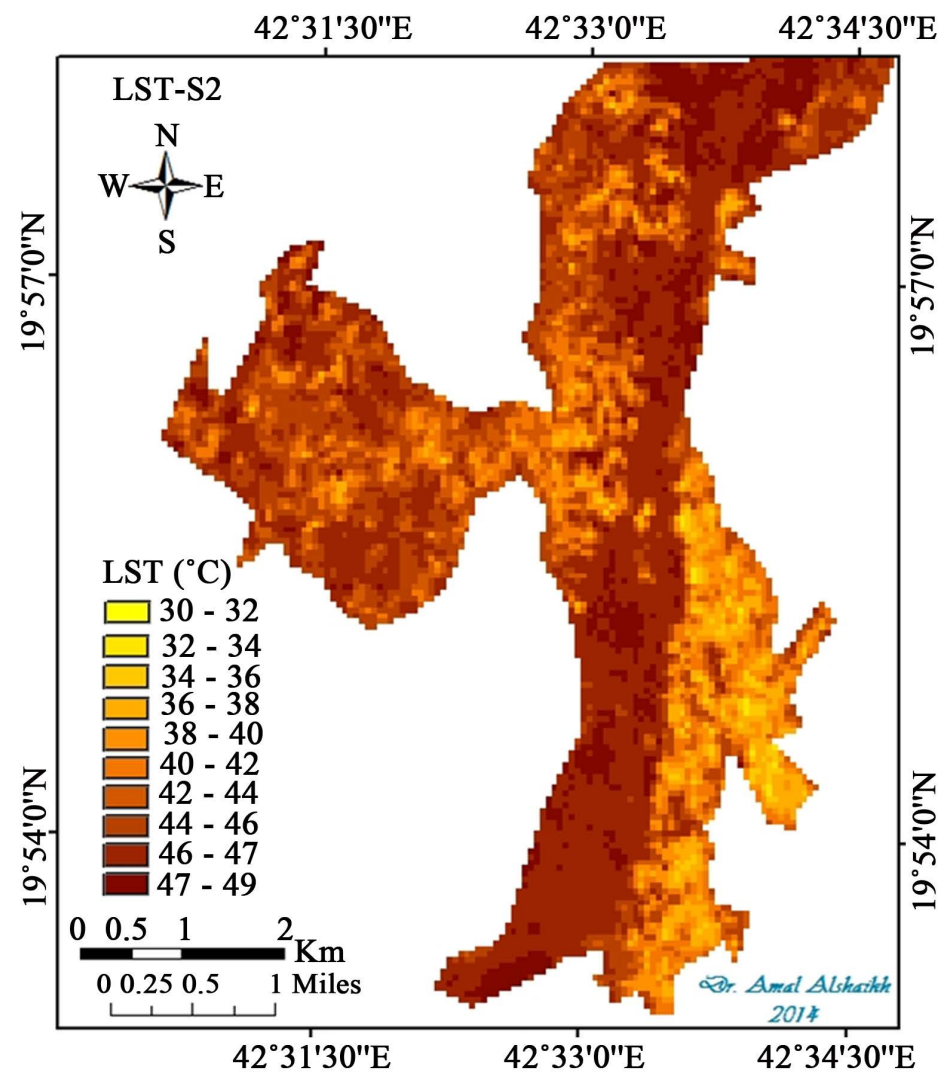

Figure 8. NDVI Value in the second part. 


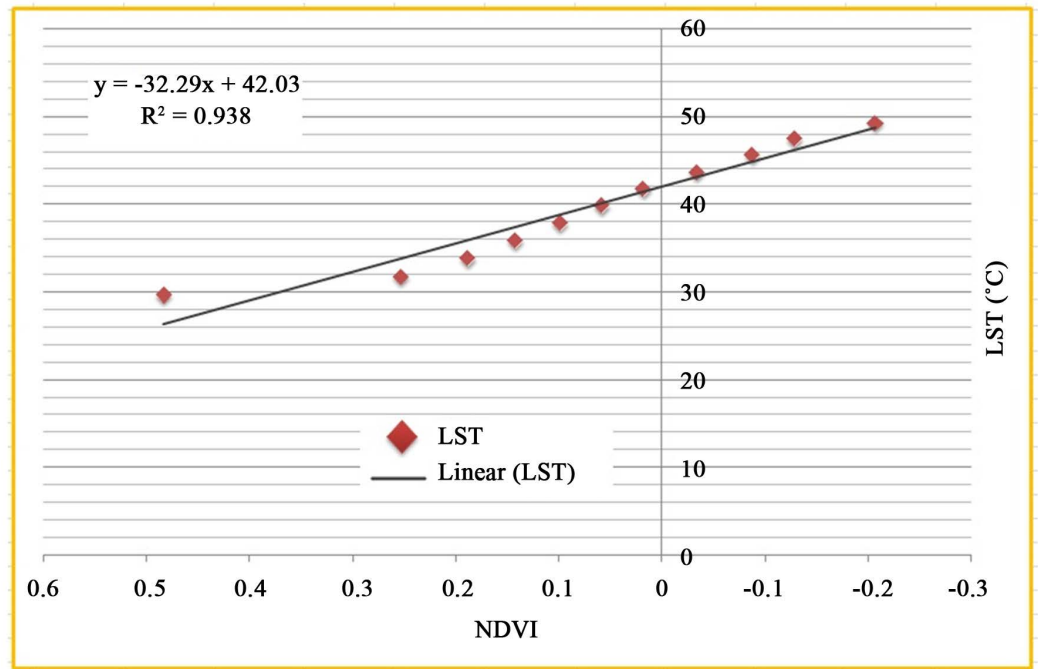

Figure 9. Relationship between LST and NDVI at part 2.

Table 5. LST and NDVI measurement at part 2.

\begin{tabular}{|c|c|c|c|c|}
\hline Pixel Value & Radiance & LST (Kelvin) & LST (Degree) & NDVI_VALUE \\
\hline 164 & 9.264370079 & 302.633713 & 29.633713 & 0.4839 \\
\hline 171 & 9.52480315 & 304.5968955 & 31.5968955 & 0.25346 \\
\hline 179 & 9.822440945 & 306.804921 & 33.804921 & 0.1884 \\
\hline 186 & 10.08287402 & 308.7072487 & 35.7072487 & 0.14231 \\
\hline 194 & 10.38051181 & 310.849022 & 37.849022 & 0.098943 \\
\hline 201 & 10.64094488 & 312.6960558 & 39.6960558 & 0.058281 \\
\hline 209 & 10.93858268 & 314.7774719 & 41.7774719 & 0.01762 \\
\hline 216 & 11.19901575 & 316.5740054 & 43.5740054 & -0.033885 \\
\hline 224 & 11.49665354 & 318.6001664 & 45.6001664 & -0.0881 \\
\hline 231 & 11.75708661 & 320.3503644 & 47.3503644 & -0.12876 \\
\hline 239 & 12.05472441 & 322.3257189 & 49.3257189 & -0.20737 \\
\hline
\end{tabular}

is 0.16 to 0.23 . Table 8 and Figure 16 show that a negative correlation coefficient of 0.94 characterizes the relation between the two parameters.

LST and NDVI measurement at several locations). LST (Kelvin) $=(306.2563744-321.5880036)$. LST (Celsius $)=\left(33^{\circ} \mathrm{C}-49^{\circ} \mathrm{C}\right)$. NDVI value $(0.169-0.229) . \mathrm{R}=-0.942713 . \mathrm{R}^{2}=0.888$.

Table 9 and Table 10 summaries the overall obtained results related to SLT and NDVI values found in different study portions. It can be outlined that the abundance of vegetation cover is one of the most influential in controlling (LST) in Wadi Bisha. As per the (NDVI values) the data indicates that areas having lowest surface temperatures were rich in vegetation (dense vegetation). A clear example may be highlighted at the part 4 of Wadi Pisha, where the Lowest LST was $\left(28^{\circ} \mathrm{C}\right)$ and highest NDVI $(0.41)$ are recorded. Also, part 2 includes the bar land area of highest LST $\left(49^{\circ} \mathrm{C}\right)$ characterized by the lowest NDVI value $(-0.20)$.

The statistical test of the obtained data identified the relationship between vegetation cover and the land surface temperature. The correlation between the (VC) and the (LST) over (50) locations in the study area is quite significant. This means that the increased vegetation cover (VC) indicates decrease in (LST), and the decreased vegetation cover (VC) indicates increased (LST). 


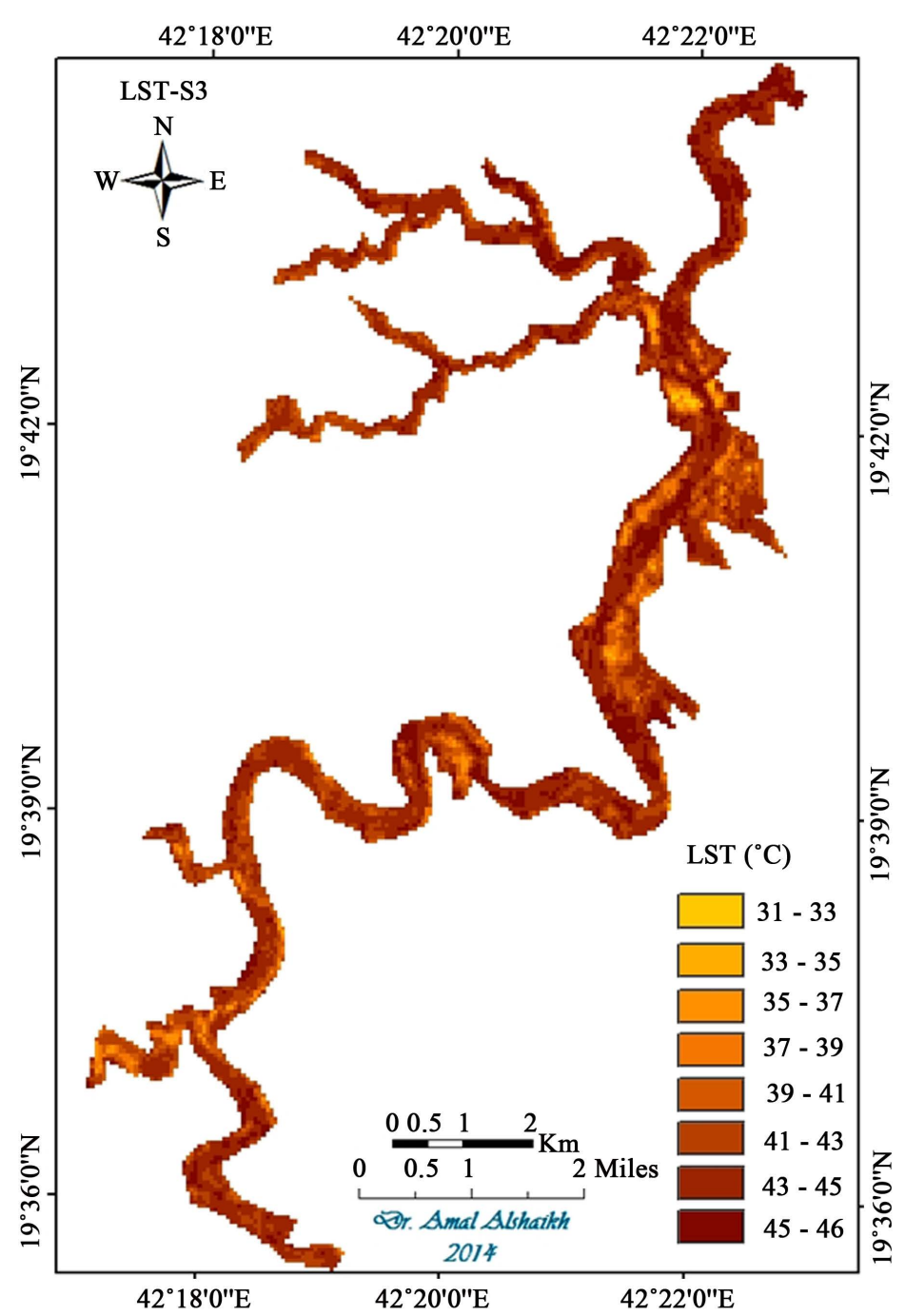

Figure 10. LST (Celsius) in the third part.

Table 6. LST and NDVI measurement at part 3.

\begin{tabular}{ccccc}
\hline Pixel Value & Radiance & LST (Kelvin) & LST (Degree) & NDVI_VALUE \\
\hline 170 & 9.487598425 & 304.3182571 & 31.3182571 & 0.2874 \\
177 & 9.748031496 & 306.2563744 & 33.2563744 & 0.1675 \\
184 & 10.00846457 & 308.1664763 & 35.1664763 & 0.1224 \\
191 & 10.26889764 & 310.049796 & 37.049796 & 0.08309 \\
198 & 10.52933071 & 311.9074828 & 49.000000 & 0.0497 \\
205 & 10.78976378 & 313.7406093 & 40.7406093 & 0.01631 \\
212 & 11.05019685 & 315.5501786 & 42.5501786 & -0.03082 \\
219 & 11.31062992 & 317.33713 & 44.33713 & -0.1506 \\
227 & 11.60826772 & 319.3527926 & 46.3527926 & -0.2135 \\
\hline
\end{tabular}




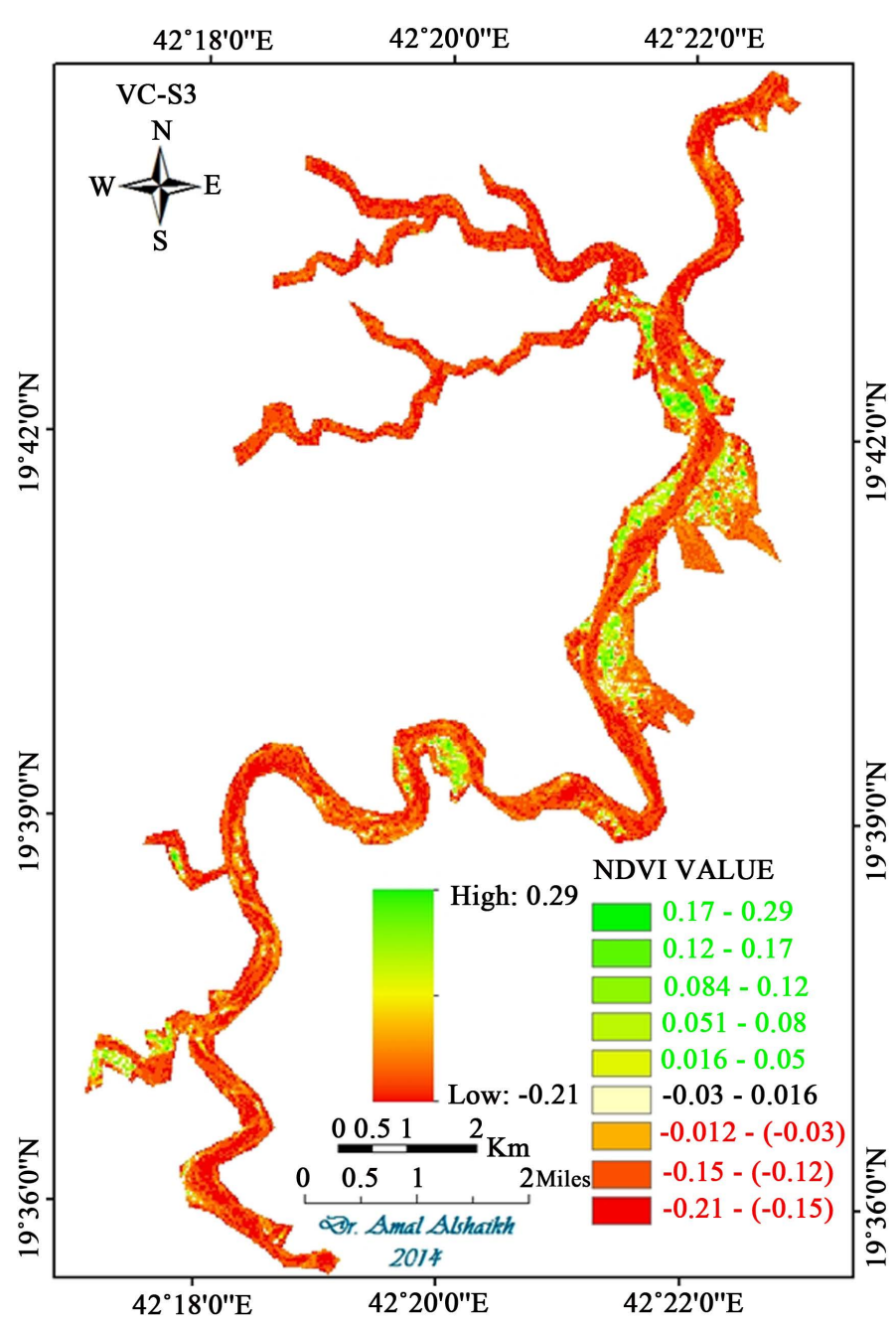

Figure 11. NDVI Value in the third part.

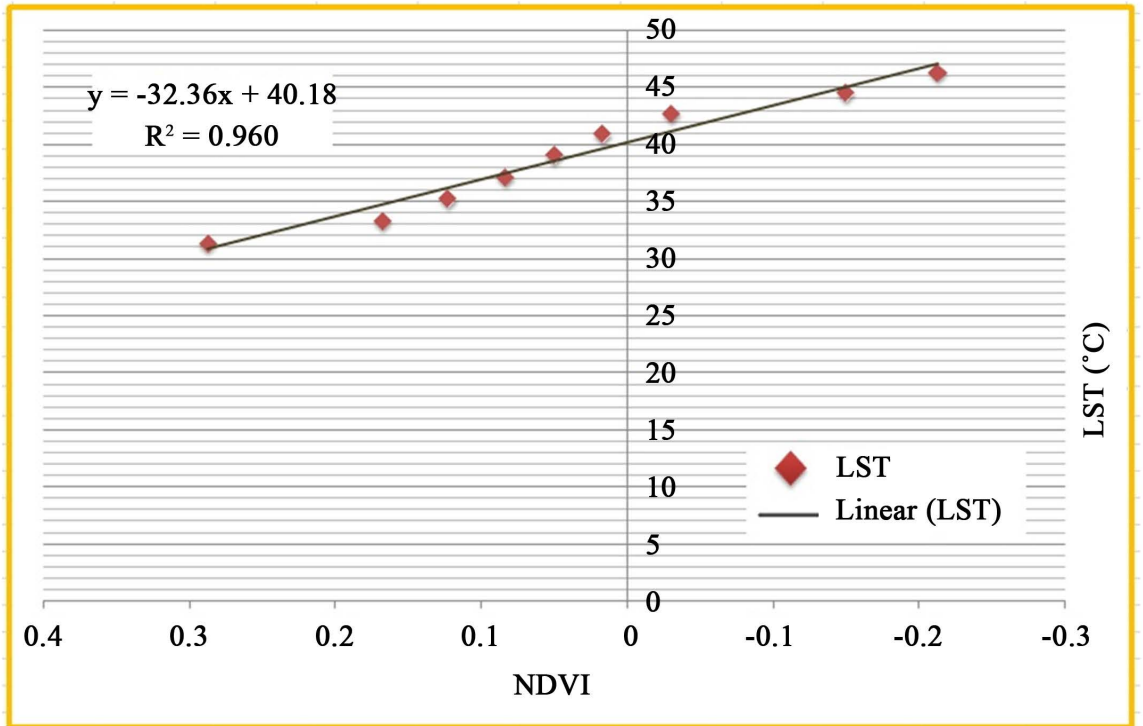

Figure 12. Relationship between LST and NDVI at part 3. 


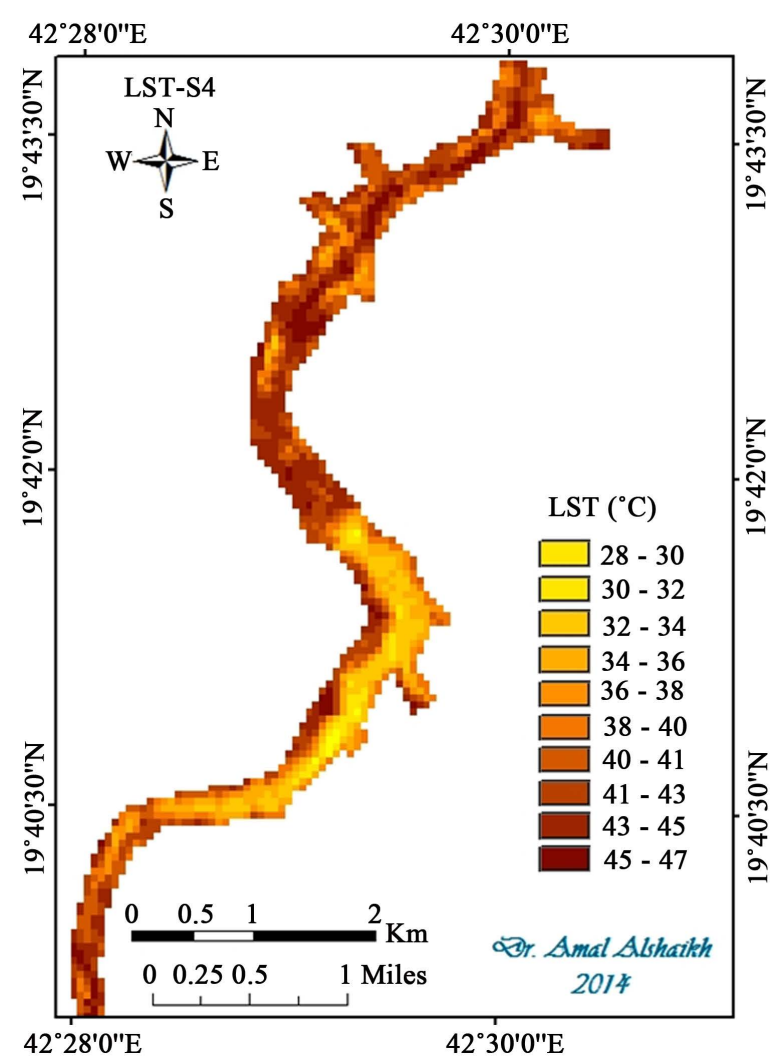

Figure 13. LST (Celsius) in the fourth part.

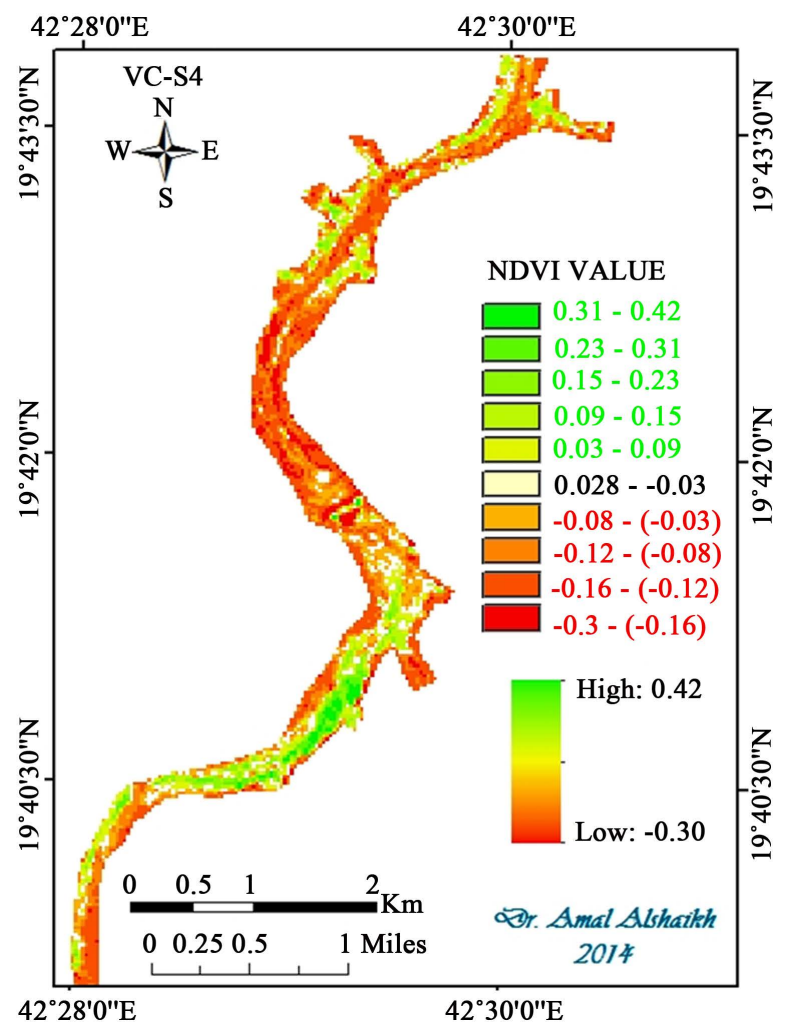

Figure 14. NDVI value in the fourth part. 


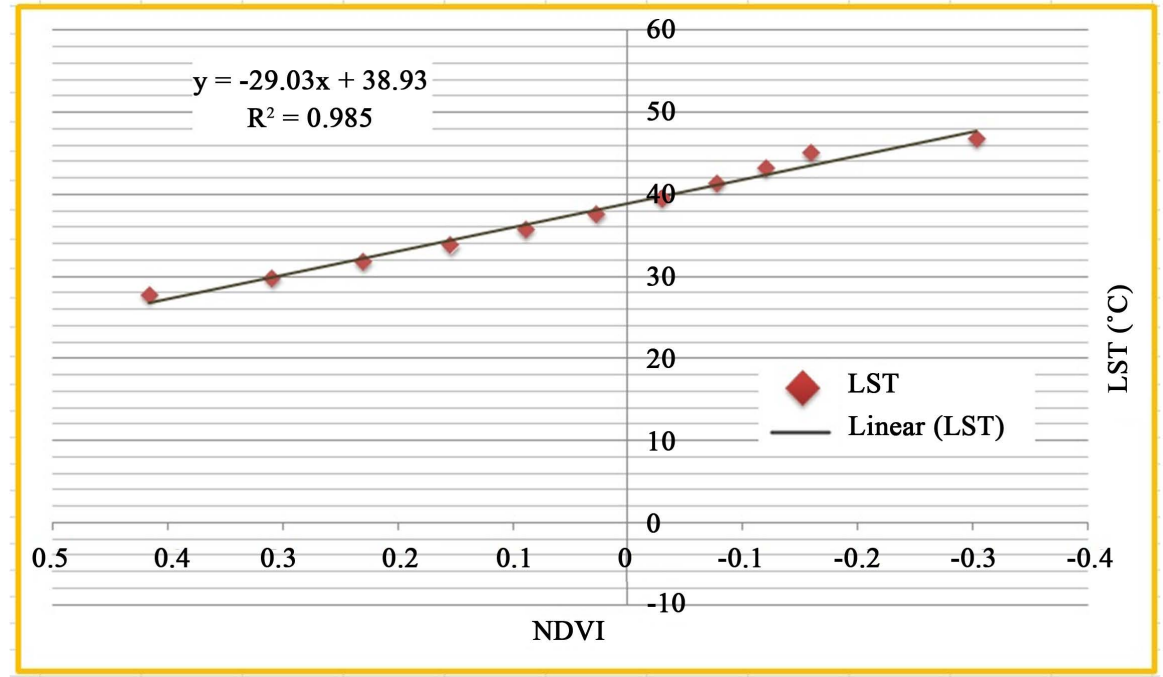

Figure 15. Relationship between LST and NDVI at part 4.

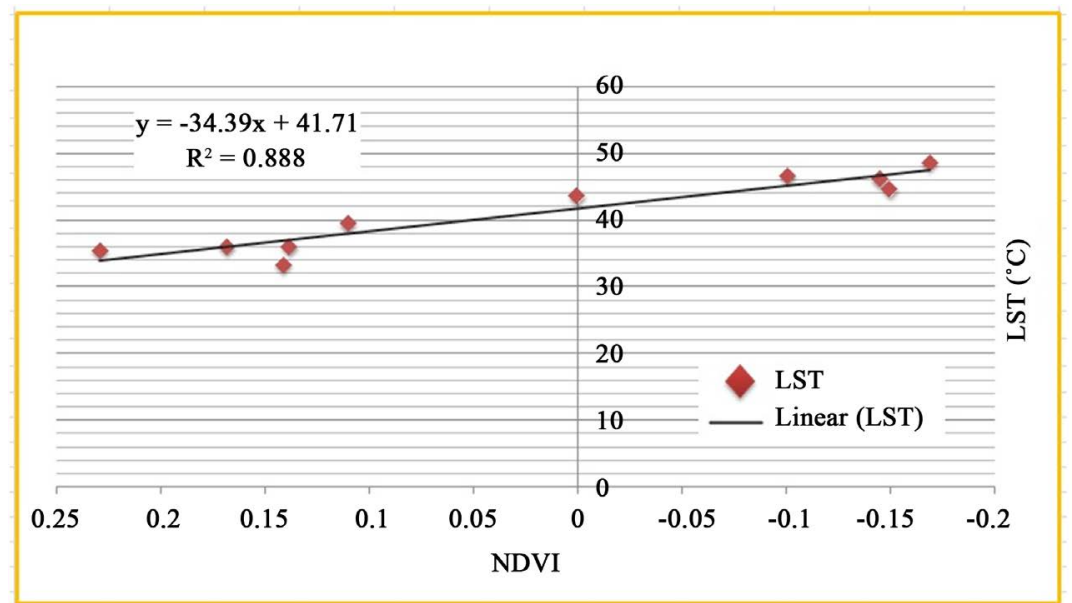

Figure 16. Relationship between LST and NDVI at several locations.

Table 7. LST and NDVI measurement at part 4.

\begin{tabular}{cccc}
\hline Pixel Value & Radiance & LST (Kelvin) & LST (Degree) \\
\hline 157 & 9.003937008 & 300.6399705 & 27.6399705 \\
164 & 9.264370079 & 302.633713 & 29.633713 \\
171 & 9.52480315 & 304.5968955 & 31.5968955 \\
178 & 9.78523622 & 306.5309316 & 33.5309316 \\
186 & 10.08287402 & 308.7072487 & 35.7072487 \\
193 & 10.34330709 & 310.583131 & 37.583131 \\
200 & 10.60374016 & 312.4336943 & 39.4336943 \\
207 & 10.86417323 & 314.2599907 & 0.0893 \\
214 & 11.1246063 & 316.0630045 & 41.2599907 \\
221 & 11.38503937 & 317.8436579 & 43.0630045 \\
229 & 11.68267717 & 319.8524179 & -0.0293 \\
\end{tabular}


Table 8. LST and NDVI measurement at several locations.

\begin{tabular}{cccccc}
\hline No. & Lat & Long & LST (Kelvin) & LST (Degree) & NDVI_VALUE \\
\hline 1 & 195030 & 422453 & 306.2563744 & 33.2563744 & 0.141 \\
2 & 195017 & 422502 & 317.5906145 & 44.5906145 & -0.15 \\
3 & 195054 & 422735 & 319.1023446 & 46.1023446 & -0.145 \\
4 & 195037 & 422449 & 308.9768239 & 35.9768239 & 0.138 \\
5 & 202321 & 424904 & 308.437134 & 35.437134 & 0.229 \\
6 & 202807 & 424929 & 319.6028162 & 46.6028162 & -0.101 \\
7 & 203547 & 425922 & 316.5740054 & 43.5740054 & 0 \\
8 & 203535 & 425902 & 312.4336943 & 39.4336943 & 0.11 \\
9 & 195033 & 422732 & 308.9768239 & 35.9768239 & 0.168 \\
10 & 203816 & 425613 & 321.5880036 & 48.5880036 & -0.169 \\
\hline
\end{tabular}

Table 9. Conclusions from analyzing the (VC) and (LST) values.

\begin{tabular}{|c|c|c|c|c|c|}
\hline Wadi Bisha & Part-1 & Part-2 & Part-3 & Part-4 & Several Locations \\
\hline LST (Kelvin) & $303-320$ & $302-322$ & $304-319$ & $300-319$ & $306-321$ \\
\hline LST (Celsius) & $30^{\circ} \mathrm{C}-48^{\circ} \mathrm{C}$ & $30^{\circ} \mathrm{C}-49^{\circ} \mathrm{C}$ & $31^{\circ} \mathrm{C}-46^{\circ} \mathrm{C}$ & $28^{\circ} \mathrm{C}-47^{\circ} \mathrm{C}$ & $33^{\circ} \mathrm{C}-49^{\circ} \mathrm{C}$ \\
\hline NDVI (Values) & $0.19-0.34$ & $0.2-0.48$ & $0.21-0.29$ & $0.303-0.42$ & $0.169-0.229$ \\
\hline
\end{tabular}

Table 10. Correlation coefficient between (VC) and (LST).

\begin{tabular}{cccccc}
\hline Wadi Bisha & Part-1 & Part-2 & Part-3 & Part-4 & 0.99245 \\
$\mathrm{R}$ & 0.98322 & 0.96896 & 0.97987 & 0.942713 \\
$\mathrm{R}^{2}$ & 0.966 & 0.938 & 0.960 & 0.985 & 0.888 \\
\hline
\end{tabular}

\section{Conclusions}

As Land surface temperature (LST) controls the surface heat and water exchange with atmosphere, Land use/ Cover is very important factor having a significant impact on Erath Ecosystem. As land surface temperature is considered the thermal landscape emission, influence of landscape on controlling surface heat and water exchange with atmosphere can be predicted. The concrete conclusion of the current research can be outlined as follows:

- Remote-sensing data is the most important data sources in land use modeling.

- Land's surface temperature is affected by many factors; the most important are richness of water and vegetation.

- There is a strong negative relationship between LST and vegetation cover.

- The temperature was increased in the urban areas.

\section{Recommendations}

It is possible to recommend the following:

1. Availability and continuity of Satellite remote sensing data is required to support controlling the ecosystem.

2. Continuous monitoring of vegetation cover conditions and mapping is recommended in WadiBisha for its ecological tourism potentialities.

3. Encouraging research and studies related to the drought in WadiBisha to support its environmental conservation and sustainable development. 
4. Presidency of Meteorology and Environment (PME) should continue their development and ensure the adoption of flexible land cover validation protocols.

\section{References}

[1] Ahmed, A., Noorazuan, H. and Zolkepli, B. (2006) Estimation of Land Surface Temperature Using Landsat Tm Thermal Infrared in Selangor-Negeri Sembilan. Proceedings of the National Seminar on Science and Its Applications in Industry (SSASI 2006), Malacca, 14-15 February 2006.

[2] Hassan, Q.K. and Rahman, K.M. (2012) Applicability of Remote Sensing-Based Surface Temperature Regimes in Determining Deciduous Phenology over Boreal Forest. Journal of Plant Ecology, 6, 84-91.

[3] Dickinson, R.E. (2010) Land Surface Skin Temperature Climatology: Benefitting from the Strengths of Satellite Observations. Environmental Research Letters, 5, Article ID: 044004. http://dx.doi.org/10.1088/1748-9326/5/4/044004

[4] Sun, D. and Pinker, T. (2004) Case Study of Soil Moisture Effect on Land Surface Temperature Retrieval. IEEE Geoscience and Remote Sensing Letters, 1, 127. http://dx.doi.org/10.1109/LGRS.2004.824749

[5] Markham, B.L. and Barker, J.L. (1986) Landsat MSS and TM Post-Calibration Dynamic Rangers, Exoatmospheric Reflectance and At-Satellite Temperatures. EOSAT Landsat Tech. Notes, 3-8.

[6] Schott, J.R. and Volchok, W.J. (1985) Thematic Mapper Thermal Infrared Calibration. Photogrammetric Engineering and Remote Sensing, 51, 1351-1357.

[7] Townshend, J.R.G. and Justice, C.O. (1986) Analysis of the Dynamics of African Vegetation Using the Normalized Difference Vegetation Index. International Journal of Remote Sensing, 8, 1189-1207. http://dx.doi.org/10.1080/01431168708954764

[8] Barsi, J.A., Barker, J.L. and Schott, J.R. (2003) An Atmospheric Correction Parameter Calculator for a Single Thermal Band Earth-Sensing Instrument. IGARSS 03, Toulouse, 21-25 July 2003.

[9] Govindha Raj, B. and Fleming, K. (2008) Surface Temperature Estimation from Landsat ETM+ Data for a Part of the Baspa Basin, NW Himalaya, India. Bulletin of Glaciological Research, 25, 19-26.

[10] Sobrino, J.A., Jiménez-Muñoz, J.C., Zarco-Tejada, P.J., Sepulcre-Cantó, G. and de Miguel, E. (2006) Land Surface Temperature Derived from Airborne Hyperspectral Scanner Thermal Infrared Data. Remote Sensing of Environment, 102, 99-115. http://dx.doi.org/10.1016/j.rse.2006.02.001

[11] USGS (2015) LANDSAT 8 (L8) Data Users Handbook. Department of the Interior US Geological Survey, LSDS-1574 Version 1.0, 105. 